مدلسازى جريان ترجيحى با استفاده از مدل موج سينماتيك- يخشى (KDW) در خاك و نقش ماكرويورها در ايجاد آن

\author{
محمدرضا ميرزايى "' و استفان قوى'
}

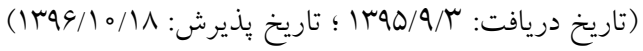

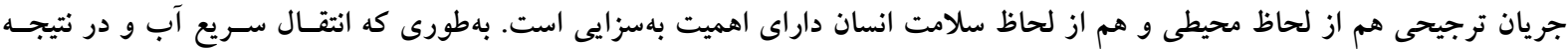

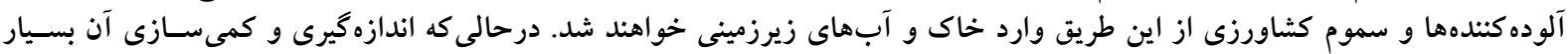

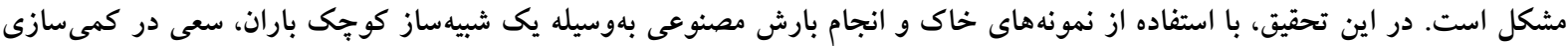

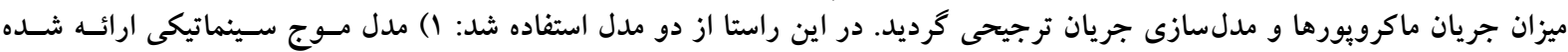

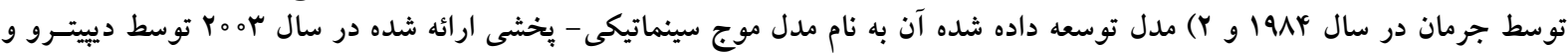

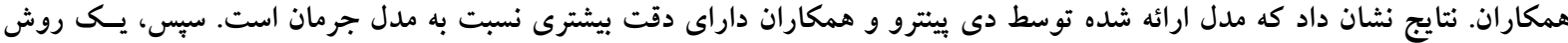

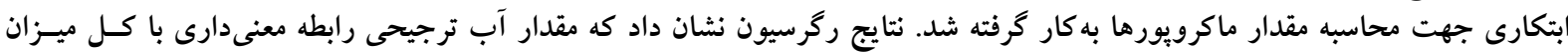

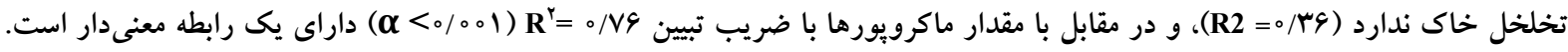

جكيده

وازههاى كليدى: جريان ترجيحى، مدل موج سينماتيك، ماكرويور، محيط متخلخل، شبيهساز باران

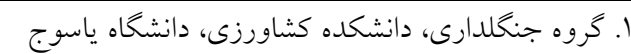

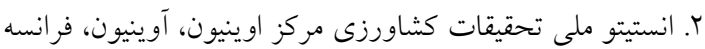

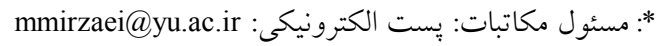




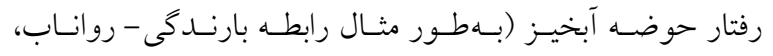

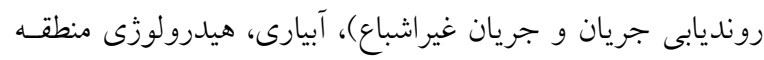

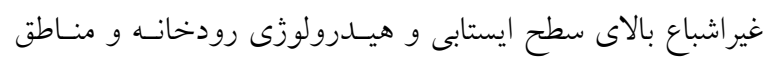

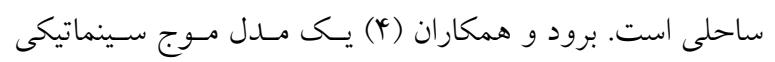

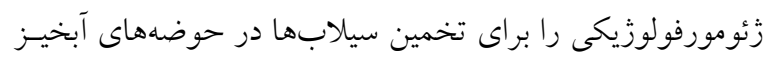
كوجكى آلبى در سوئيس ارائه كردهاند. بلهور كلى خاكهايى كه داراى ساختار هستند، مسيرهاى قابل

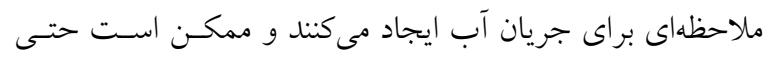

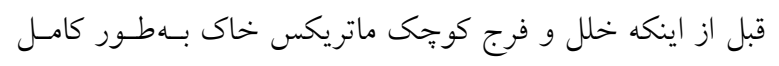

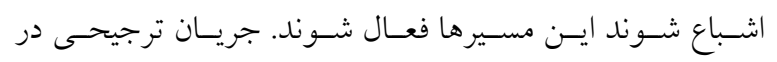

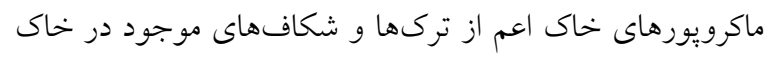

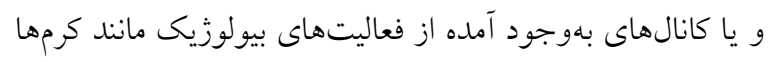

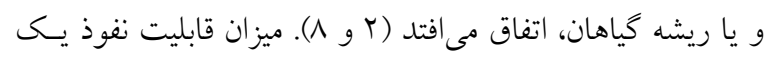

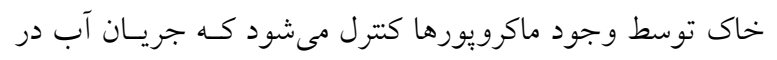
آنها از نيروى موئينگى ييروى نمى كند.

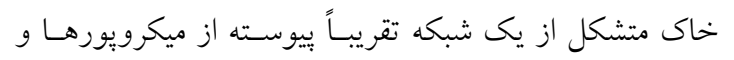

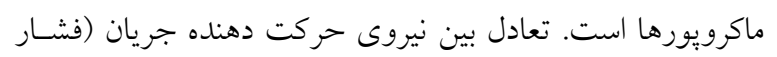

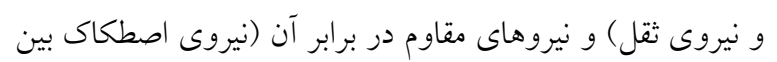

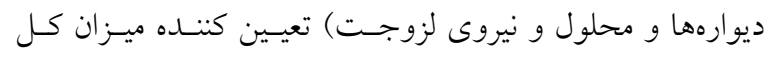

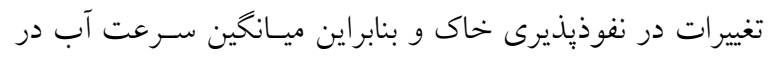

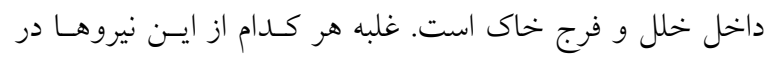

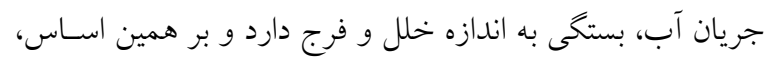
رفتار هيدروليكى در مقايسهاى مختلف تغيير بيدا مى كند. جريان

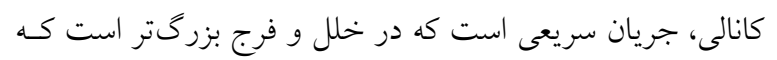

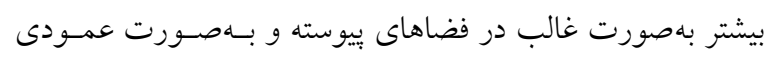
هستند. جرمان (9) مدل مـوج سـينماتيكى را بـراى توضسيح جريـان

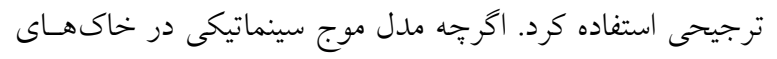

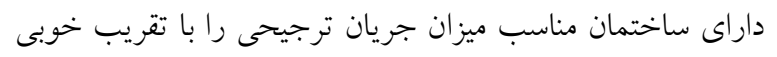

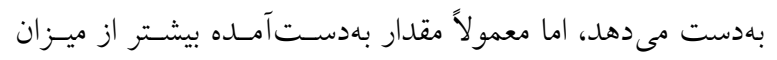
واقعى است (0 1). عاملى كه در كاهش اثر موج سينماتيكى تـأثير

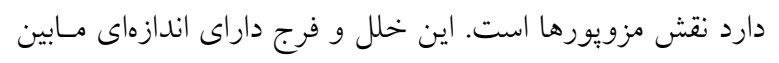

\section{مقدمه}

جريان ترجيحى (جريان كانالى، ماكرويورها يا ميانبر) در خـاك،

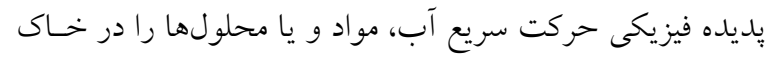

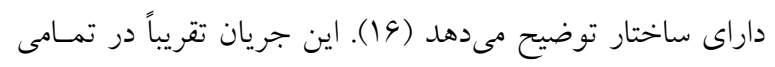

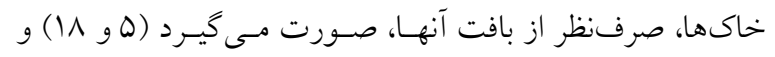

$$
\text { اغلب آن را به وجود ماكرويورها ربط مى دهند. }
$$

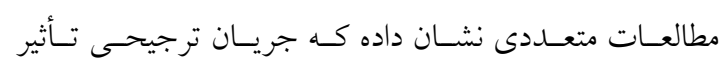

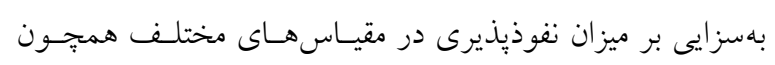

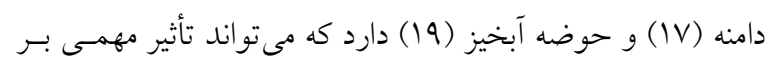

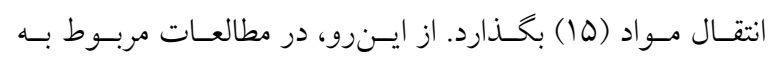

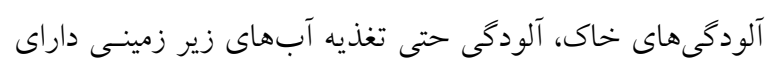

$$
\text { اهميت بهسزايى است. }
$$

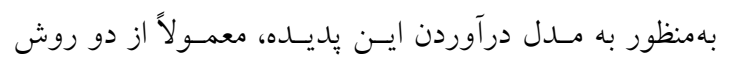

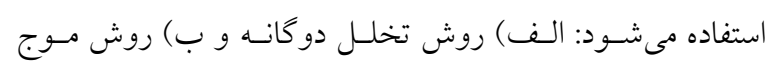

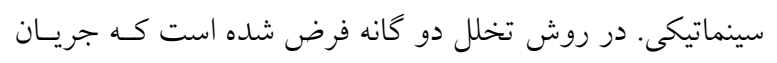

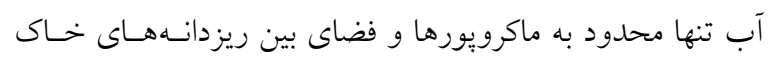

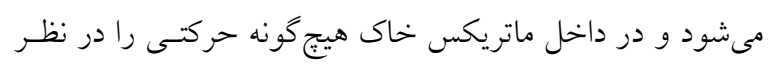

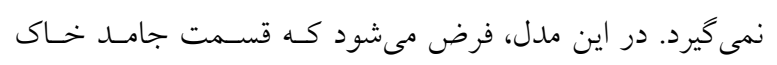

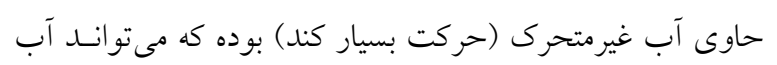

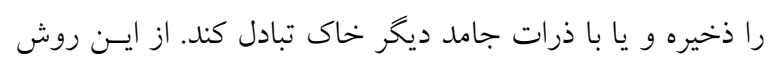

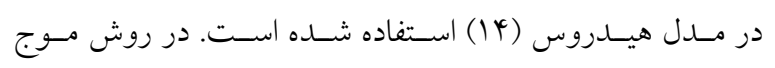
سينماتيكى، تخلل خاك به دو قسمت ميكرويورها و ماكرويورهـا

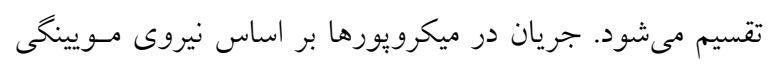

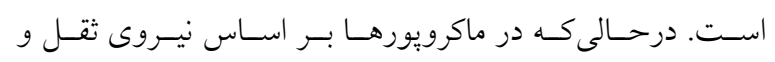

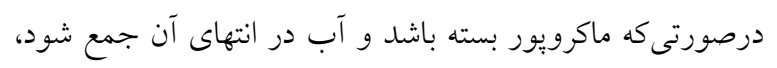

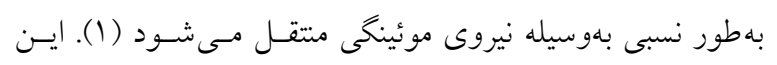

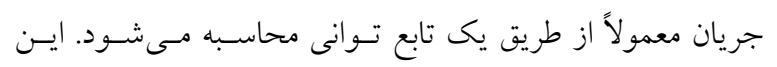

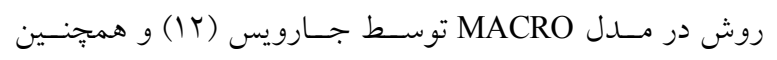
توسط كركو (11) در مدل VIMAC بهكار برده شده است.

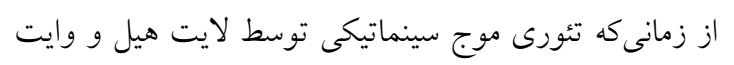

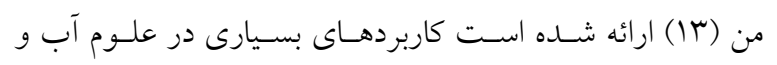
محيط زيست بيدا كرده است. از كاربردهاى اين تئورى، توضسيح 
مدلسازى جريان ترجيحى با استفاده از مدل موج سينماتيك- يخشى (KDW)...

نفوذيذيرى انتقال و مـواد در داخـل خـاك اسـت. بـهـطـورىكـه

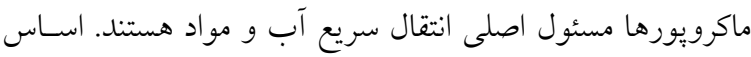
اين مطالعه در مدلسازى، تحقيق دى ييترو و همكاران (V) استـان.

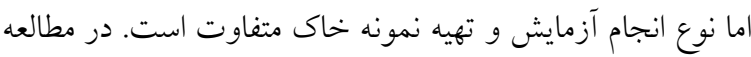

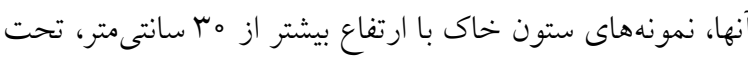

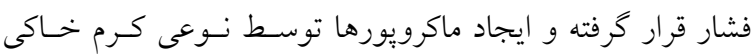

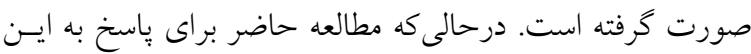

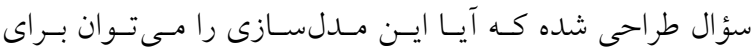

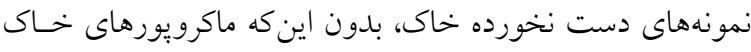

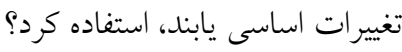

\section{مواد و روشها - - ماد}

تئورى

بخش تئورى اين تحقيق توسط دى ييترو و همكاران (V) شـرح

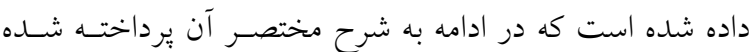

مدل موج سينماتيكى - بخشى (KDW) جريان ترجيحى از بين

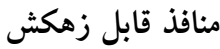

فرض كنيم كه W نشان دهنده ميزان آب حجمى متحرى (كسه در

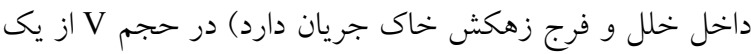
يروفيل خاك باشد. در اينصسورت w مشستق جزئسى اول برحسب زمان و uريان حجمى مربوط به آب متحسرى بـهـ

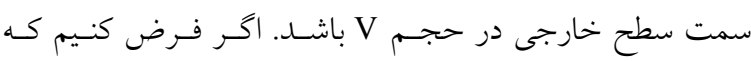

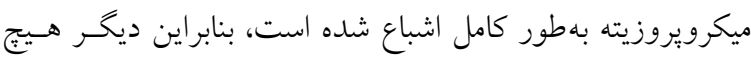

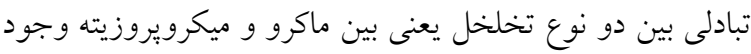
نخواهد داشت. در اينصورت تغييرات رطوبت به زمان در داخل

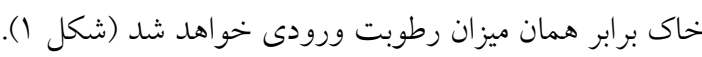

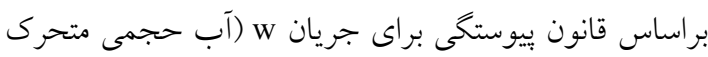

در داخل منافذ قابل زهكش) را مىتوان بهصورت زير برير بيان كرد: $\frac{\partial \mathrm{w}}{\partial \mathrm{t}}+\nabla \cdot \mathrm{u}=$ 。
اندازه ماكرويورها و ميكرويوزها هسـتند كـه نقـش مهمسى را در جريان ترجيحسى ايفـا مسى كنــد. در مزويورهــا نيـروى مـويينخى

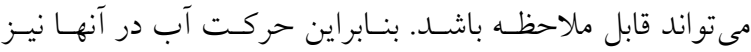

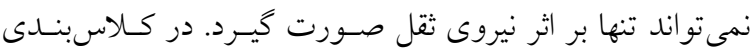

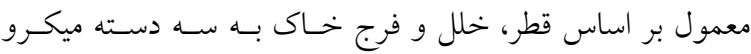

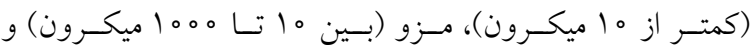

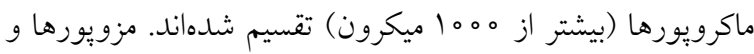

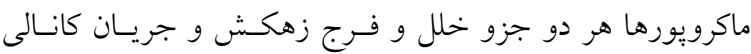

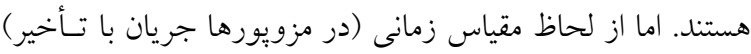

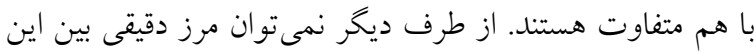

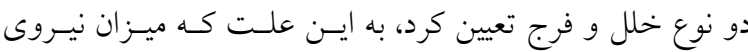

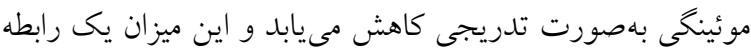

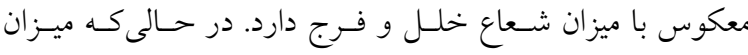

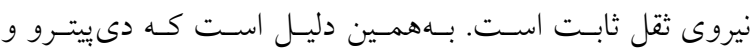

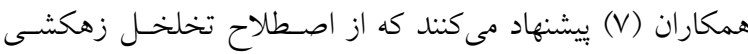
استفاده شود كه اشاره به تخلخلى مس كنــ اصند كه بتانسيل شركت در تشكيل آب ترجيحى را دارند كـه بـه آنها

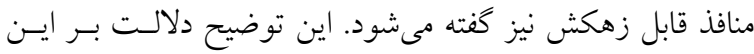

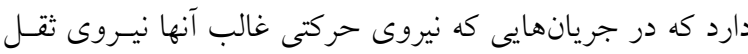

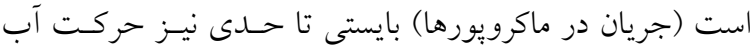

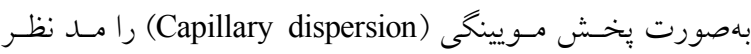

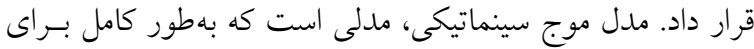

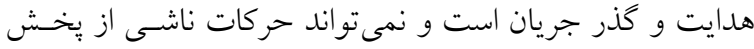

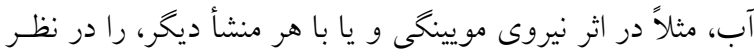

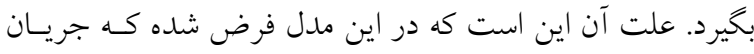

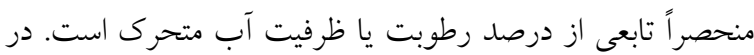

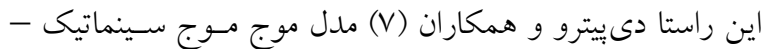
KDW يخشى (kinematic-dispersive wave) كـه بـه اختصـار ناميده مسى شـود را، بـا اضـافه كـردن نقـش مزويورهـا بـهـ مـــل

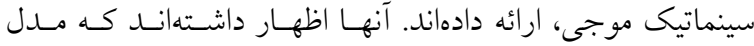
Lاراى دقتى بالاتر از مدل سيتماتيك موجى است.

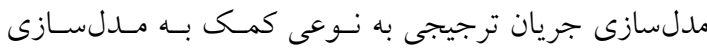




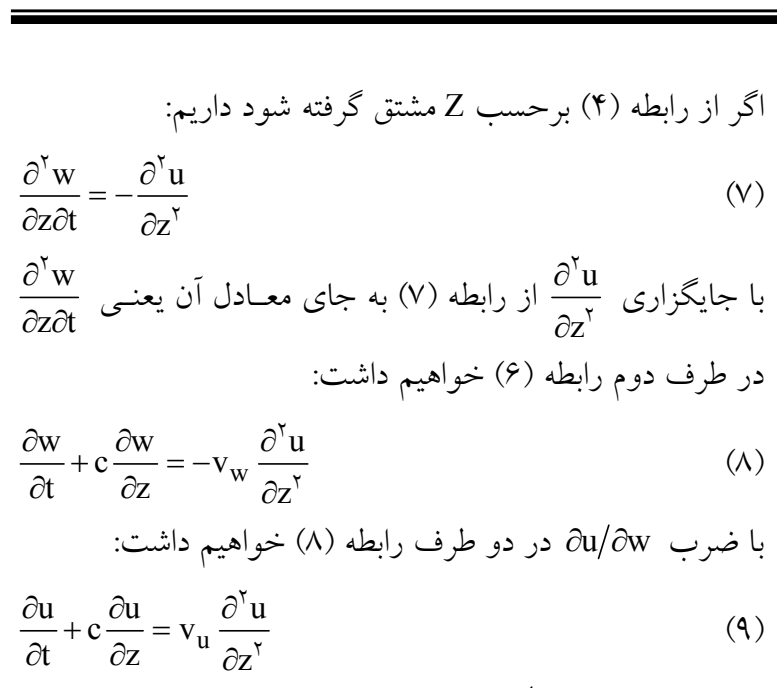
كه در آن v هر دو رابطه (4) و (9) بهترتيب روابـط غيرخطى هـدايتى - (9) -

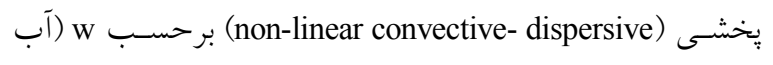
حجمى متحرى داخل تخلخل قابـل زهكشش) و u (آب حجمسى متحرى خروجى) هستند. تقريب سينماتيكى دو اصطلاح سمت جِّ در رابطه (9) ميزان مشتق مجموع زمانى تابع جريان u(z,t) را نشان مي دهد كه شيب هر منحنى (c) در هر نقطه قرار كرفته در صفحه (z,t) را نشان مىدهد. اين منحنىها را خطـوط مشخصـه (characteristic curves) رابطـهـ ديفرانسـيل مىنامند. اين اصطلاححات را مىتوان بهصورت زير نوشت: $\frac{\mathrm{du}}{\mathrm{dt}}=\frac{\partial \mathrm{u}}{\partial \mathrm{t}}+\frac{\mathrm{dz}}{\mathrm{dt}} \cdot \frac{\partial \mathrm{u}}{\partial \mathrm{z}}$

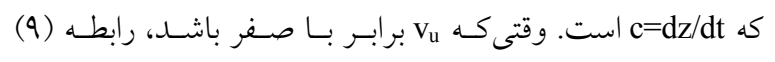
بهورت زير سادهتر مىشود: $\frac{\mathrm{du}}{\mathrm{dt}}=\frac{\partial \mathrm{u}}{\partial \mathrm{t}}+\mathrm{c}(\mathrm{w}) \frac{\partial \mathrm{u}}{\partial \mathrm{z}}=。$

اين مدل موج سينماتيكى بهصورت گسترده در مدلسـازى منسابع رابطه (11) دلالت بر اين امـر دارد كـه تـابع u(z,t) در طـول

$$
\text { آب استفاده مىشود ( آو VلV). }
$$$$
\text { منحنى هاى مشخصه بهصورت ثابت باقى مى مانند. }
$$$$
\text { براى مقادير اوليه مسئله داريم: }
$$

$-\infty<\mathrm{z}<+\infty, \mathrm{t}=\circ, \mathrm{u}=\mathrm{f}(\mathrm{z})$

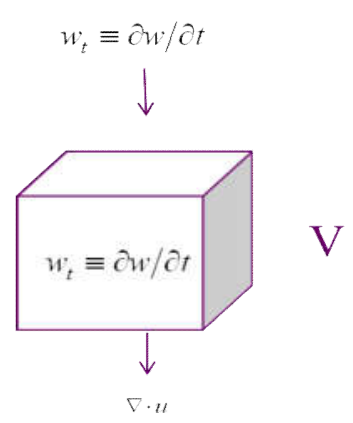

شكل ا. شماتيكى از جريان ورودى آب (wt) در حالت اشباع بودن

خاى و جريان خروجى

كه در واقع بيانخر اين است كه ميزان تغييرات رطوبت با توجه به زمان برابر است با همان مقدارى كه از منافذ قابل زهكش خـارج مى شود. حال اكر فرض ديخرى اضافه شود به اينصـورت كـه ميـزان

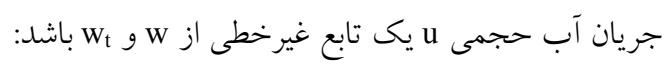
$\mathrm{u}=\mathrm{u}\left(\mathrm{w}, \mathrm{w}_{\mathrm{t}}\right)$

$$
\text { بس گر اديان مكانى جريان با مشتق گيرى از u مىشود: }
$$

$\nabla \mathrm{u}=\mathrm{c} \nabla \mathrm{w}+\mathrm{v}_{\mathrm{w}} \nabla \mathrm{w}_{\mathrm{t}}$

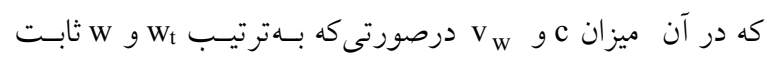

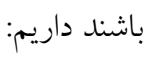

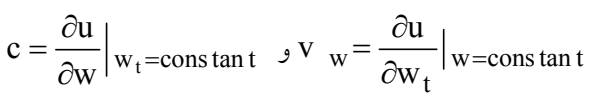

با فرض اينكه جريان آب تنها در جهت عمودى (در جهت Z) به سمت يايين مىرود، در اينصورت كراديان مكانى جريان (

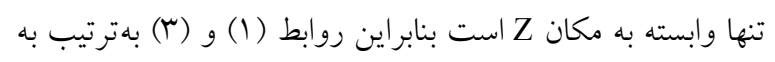
روابط زير تبديل مىشوند:

$\frac{\partial \mathrm{w}}{\partial \mathrm{t}}+\frac{\partial \mathrm{u}}{\partial \mathrm{z}}=。$

$$
\frac{\partial \mathrm{u}}{\partial \mathrm{z}}=\mathrm{c} \frac{\partial \mathrm{w}}{\partial \mathrm{z}}+\mathrm{v}_{\mathrm{w}} \frac{\partial^{r} \mathrm{w}}{\partial \mathrm{z} \partial \mathrm{t}}
$$

با تركيب روابط (Y) و (O)، و قرار دادن معادل (ه) در رابطه (†) داريم:

$\frac{\partial \mathrm{w}}{\partial \mathrm{t}}+\mathrm{c} \frac{\partial \mathrm{w}}{\partial \mathrm{z}}=-\mathrm{v}_{\mathrm{w}} \frac{\partial^{r} \mathrm{w}}{\partial \mathrm{z} \partial \mathrm{t}}$ 
مدلسازى جريان ترجيحى با استفاده از مدل موج سينماتيك- يخشى (KDW)...

lu=(z,t)

بهعلاوه او فرض كرد كه رابطـه ميـزان جريــان آب متحــرى

$$
\text { بهصورت يك رابطه توانى بهصورت زير است: }
$$

$\mathrm{u}=\mathrm{aw}^{\mathrm{b}}$

$$
\text { كه در آن a و [ }
$$

ايجاب تصحيح درجه دوم و راه حلهاى عددى براى حل آنها

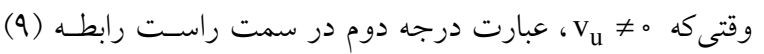
ميزان يخش را نشان مىدهد. با استفاده از رابطـه (0) مسىتـوان رابطه (9) را بهصورت زير دوباره نويسى كرد:

$\frac{\mathrm{du}}{\mathrm{dt}}=\mathrm{v}_{\mathrm{u}} \frac{\partial^{r} \mathrm{u}}{\partial \mathrm{z}^{r}}$

رابطه (10) نشان مىدهد كه جريان uيخر در هر مشخصـه ثابـت نيست و تغييرات آن بستخى به تغييرات مكانى شـيب جريـان دارد. فرض مىشود كه تابع داده شده در رابطه (Y) بهصورت زير است: $\mathrm{u}=\mathrm{f}(\mathrm{w})+\mathrm{g}\left(\mathrm{w}_{\mathrm{t}}\right)$

$$
f(w)=b w^{a} \quad, g\left(w_{t}\right)=-v_{w}\left(\frac{\partial w}{\partial t}\right)
$$

كه ميزان a a

هستند.

رابطه 19 براى به مــدل درآوردن نتـايج بـهدست آمـده از آزمايش هاى نفوذيذيرى - زهكشى در بسيارى از خاكها توسط بـ بـ بـ دى ييترو و همكاران (V) ارائه شده است كه يكى از اهــداف مـا در اين مقاله معرفى كامـل ايسن روش و بررسـى و ارزيـابى آن است.

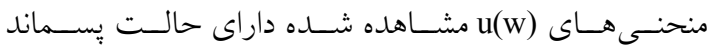
u هستند، بهطورى كه به ازاى مقادير ثابت Wysteretic) در حين نفوذيذيرى كوجى u در حين زهكث است. دى ييترو و همكاران (V) فرض كردند كه يك نيسروى اينرسسى در حين مراحل انتقالى نفوذيذيرى و زهكث توسعه مي يابد، اين نيرو متناسب است با ميزان افزايش (و بههمين ترتيب كـاهش) ميـزان آب حجمى و در حالت بايـدار صـفر اسـت. عبـارت اصـلاحى

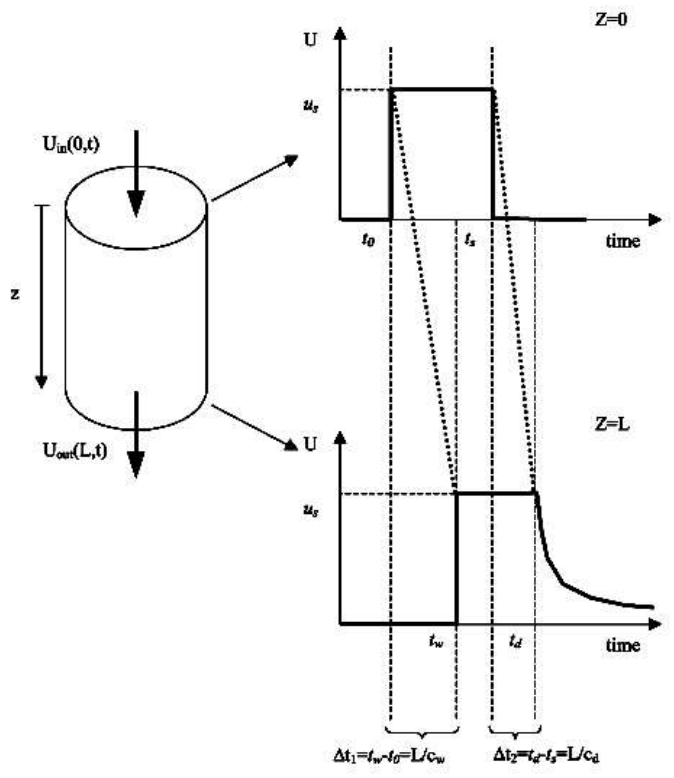

شكل r. بيشبينى هيدروگر اف خروجى بر اساس رابطه (II)،

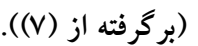

جرمان (9) رابطه (11) را با در نظر گرفتن شرايط مرزى زير حل

$\left\{\begin{array}{l}\mathrm{u}(\mathrm{z}, \mathrm{t})=\mathrm{u}_{\text {in }}(\mathrm{t}), \quad \mathrm{z}=0, \quad \mathrm{t}>0 \\ \mathrm{u}(\mathrm{z}, \mathrm{t})=\mathrm{u}_{0}, \quad \mathrm{z}>0, \quad \mathrm{t}=0\end{array}\right.$

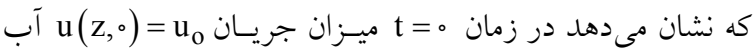
تنها بهميزان آب اوليه در داخل خاك در ارتفاعات مختلف بستخى

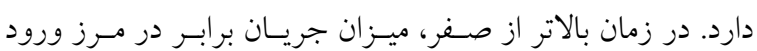

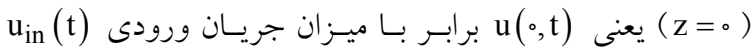
است. (tun

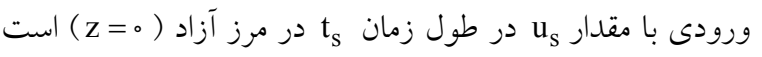

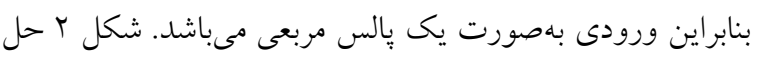
مدل موج سينماتيكى رابطه (1/) ارائه شده توسط جرمـان (9) را در يك ستون خاك با ارتفاع Z=L نشان مىدهد. اخر يـك يـالس مربعى از آب داخل ستون شود، خروجى با تأخير زمـانى خواهــ بود. مدت زمان تأخيرى رسيدن جبهههاى رطوبتى و زهكـش در طول L بهترتيب الL

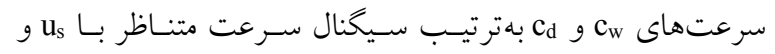


is

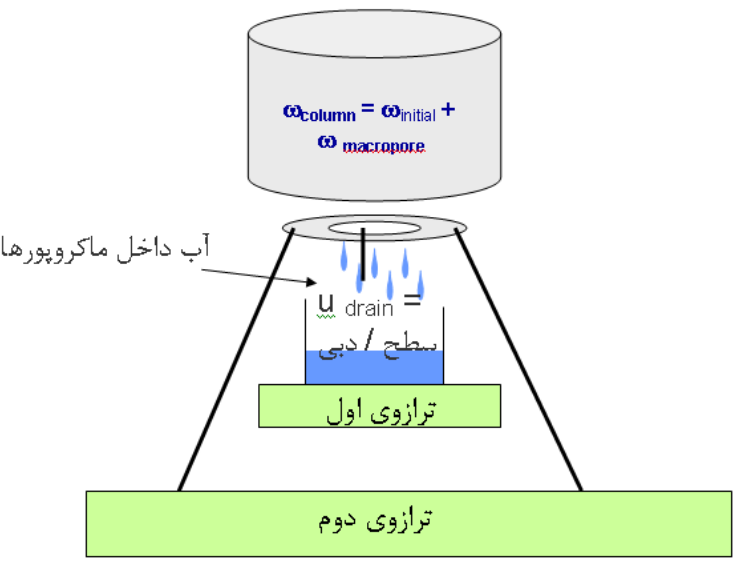

شكل س. نمايش شماتيكى از نحوه انجام آزمايش صورت گُفته در اين مطالعه، ترازوى اول فقط براى اندازهيرى ميزان آب

$$
\text { زهكث شده و ترازوى دوم ميزان آب ستون را نشان مىدهد. }
$$

روى اين نمونههـا آزمـايش نفوذيـذيرى-زهكـش صـورت كرفت. قبل از انجام اين آزمايش ابتدا نمونهها به حالت اشـباع در آورده شدند؛ سيس حدود دو ساعت قبل از شروع آزمايش بـراى هر نمونه، به نمونه اجازه زهكش شدن داده شـد تـا آبسى كـه در داخل ماكرويورها وجود دارد تخيله شود. نحوه انجام آزمايش در شكل (r) آورده شده است. همانطور كه ديـده مسى شـود نمونسه

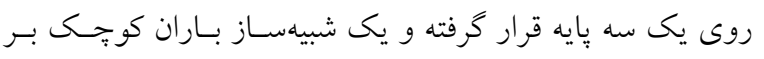
بالاى آن نصب مىشود. از يميى كوجّى كه داراى دورهاى متغير با قابليت تنظيم شدت بارندكى از شدتهاى يايين تـا بـارش بـا

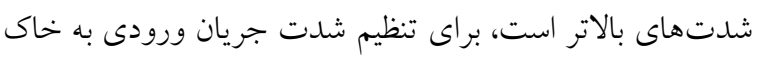
استفاده مى شود. در سطح زيرين سيلندر نمونـه، قيفى قـرار داده شده كه آب خروجى حاصل از زهكش را به درون ظرفى جهــت اندازهكيرى ميزان شدت جريان خروجى هدايت مى كند. دو ترازوى دقيق يكسى در زيــر مخـزن آب زهكـش شــده و ديخرى در زير نمونه خاك قرار مسى گيـرد. هـر دو ايـن ترازوهـا توسط يك نرمافزار از طريق كامبيوتر كنترل مىشوند و در هنخــام آزمـايش، منحنسى تغييـرات وزنسى و اخـتلاف عـددى دو تـرازو بهصورت بـرخط از طريـق نمايشـكر كـامييوتر قابـل مشـاهده و g(wt) مشتق اول زمانى ميزان آب متناسب اسـت. ايسن عبـارت اصلاحى در حين نفوذيذيرى (افزايش w) بهصورت منفى، صـفر در شرايط يايدار (ثابت بودن w) و در حين زهكش (كـاهش w) مثبت است. نحوه آزمايش خاى استفاده شده در اين مطالعه خاك لومى رسسى (clay loam) بــوده و آزمايشـات مربوطـهـ در يــايلوت آزمايشـى و آزمايشــاه فيزيك خاك انستيتو ملى تحقيقات كشاورزى در شهر اوينيون در جنوب فرانسه انجام شده است. از يك متر مربع زمسين كـه قـبلاً

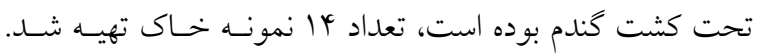
نمونههاى خاك، توسط سيلندرى دايـرهاى شـكل بـا قطر 10 و طـول تقريبسى V سـانتى متـر برداشـت شــند. ايسن سـيلندرهاى

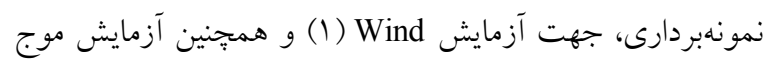
سينماتيك در آزمايشخاه مذكور داراى استاندارد لازم است. هنخام برداشت نمونه هاى خاى، سعى شد كـه سـاختمان خـاك داخـل نمونه حفظ شود. طرح نمونه گيرى تصادفى است و در حدود به درصد سطح يلات آزمايشى را در بر مى گيرد. 
شدن جريان خروجى زمانى خواهل بود كه جندين داده ثبت شده

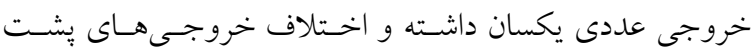

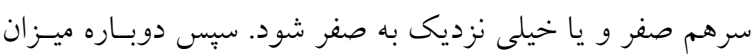

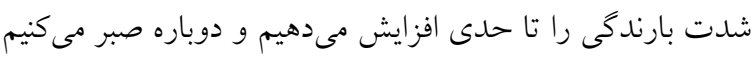

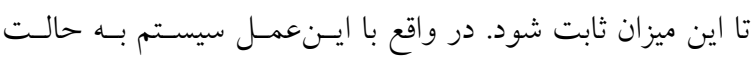

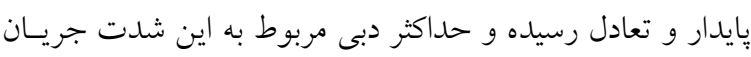

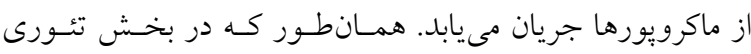

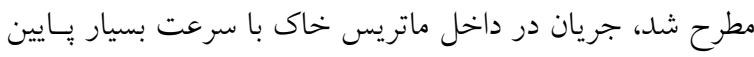

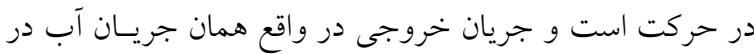

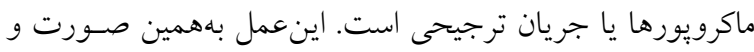

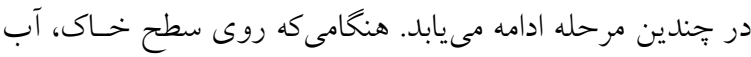

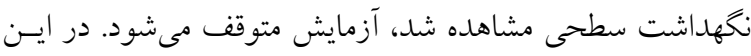
زمان ميزان شـــت ورودى از ميـزان ظرفيـت نفــوذ بيشـتر بـوده

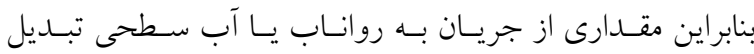
مىشود.

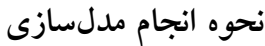

در بخش تئورى دو فرض براى مدلسازى جريان ترجيحى ارائسه

1. فرض اول توسط: جرمان (9) بيان مى كند كه جريان ترجيحى

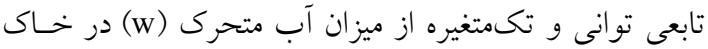
است كه بهعنوان مدل موج سينماتيكى ناميده مىشود و رابطه آن بهطور خلاصه بهصورت زير است:

$\mathrm{u}(\mathrm{w})=\mathrm{f}(\mathrm{w})=\mathrm{bw}^{\mathrm{a}}$

داراى دو بارامتر a و bه بايستى تعيين شوند.

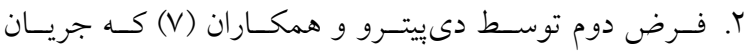

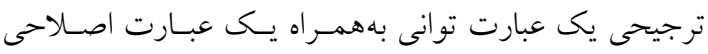

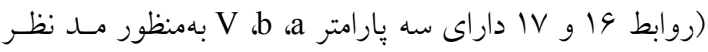

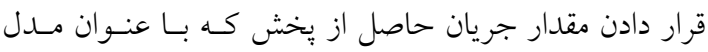

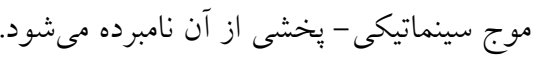
$u=f(w)+g\left(w_{t}\right)=b w^{a}-v_{w}\left(\frac{\partial w}{\partial t}\right)$

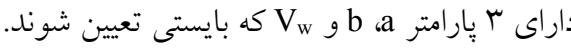

ردخيرى است. از طرف ديخر گام زمانى ثبت دادهها قابـل تنظيم

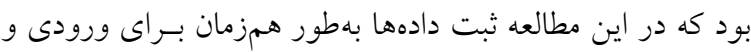

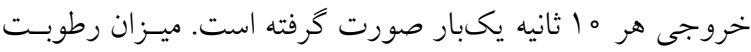
تبت شده براى ستون خاك بلصورت زير خواهد بود: $\mathrm{w}=\mathrm{w}_{\text {initial }}+\mathrm{w}_{\text {macropore }}$

W برحسب گرم نشان دهنده ميـزان جـرم آب در داخـل نمونـه، جرم آب اوليـه كـهـ مقـدار آن كمسى كمتـــ از اشـباع (gr)Winitial خواهد بـود و درنهايـت Wacropore وزن آب داخـل ماكرويورهـا است كه داراى حركت نسبتاً سريع در خاك است. ميـزان جريـان خروجى نيز بـا توجسه بـه مسـاحت و مقـدار آب خروجسى كـه بهوسيله ترازوى اول ثبت مىشود، محاسبه مىشود.

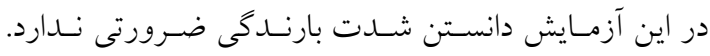
جيزى كه مهم است انجام تغييرات تدريجى در شدت بارندگى از

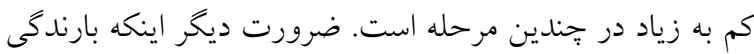
نبايستى داراى انرزى جنبشى زيادى باشد، در غير اين صورت بـا تغيير در سطح خاى باعث ايجاد سله مىشود. لايه نازى سلههاى سطحى، از طرفى، خود داراى نفوذيذيرى بسيار بـايين بـوده و از طرف ديخر باعث مسدود شدن ماكرويورها خو اهند شد. در واقع در اين آزمايش خصوصيات خاك سطحى تا حدى ناديده گرفتـه

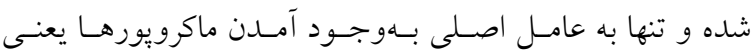
ساختمان خاك اهميت داده مىشود. بهطور مثال در اين آزمايش بايستى دقت كرد كه ترىهـاى بـزرى در سـطح خـاى موجـود نباشد؛ البته با توجه به اشباع بودن خاك، تركهاى ناشى از تغييـر حجم در نمونه به ندرت ديده خواهد شد. شروع آزمايش، با شروع بارندگى در شدت يايين است. ابتـدا شدت يايينى انتخاب مىشود و با شـدت ثابـت يـايين بـهوسيله شـبيهسـاز بـارش مصـنوعى روى سـطح خـاى بـارش صـورت مى گيرد. آب بعد از نفوذ در داخل خاى و طى طول ستون خـاك از سمت ديخر بهصورت جريان خروجسى زهكـش مسىشـود. در ابتدا كمكم بهميزان خروجى اضافه شده تا يُ از مدتى تغييـرات آب خروجى ثابت شود. در اين حالت ميـزان خروجسى حـداكثر عبور آب با توجه به شدت ورودى را خواهد داشت. عمل ثابست 


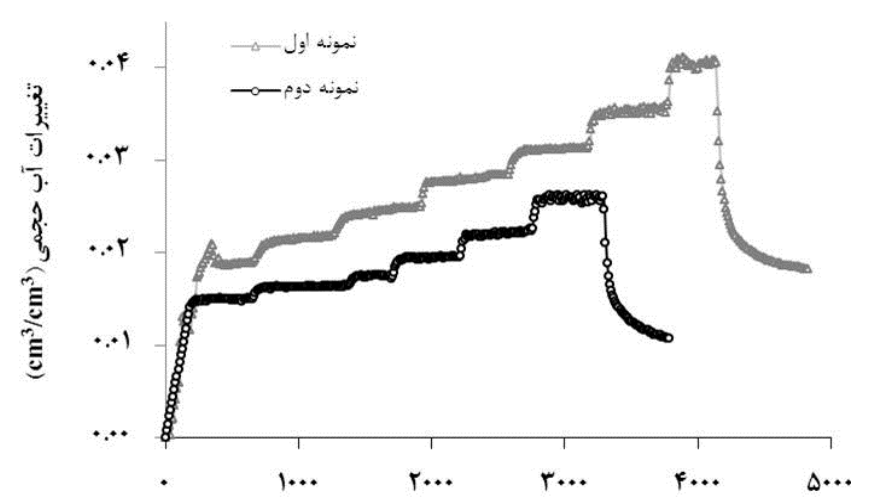

زمان (S)

شكل †. دادههاى مربوط به آزمايش نفوذيذيرى - زهكث در دو نمونه، حالت يُلكانى بهوجود آمده براى رسيدن به حالت تعادل در خروجى،

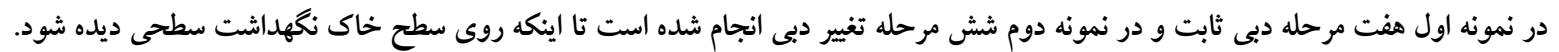

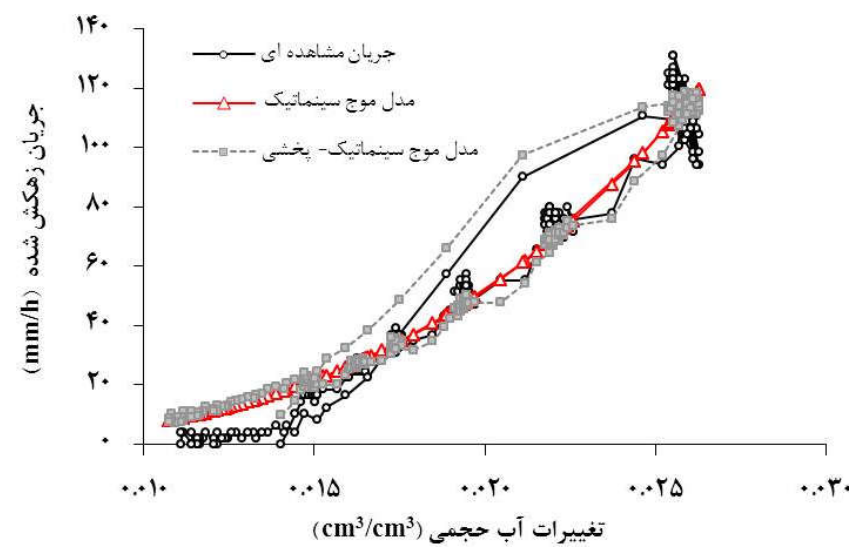

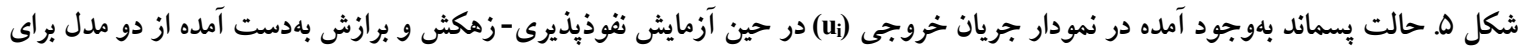

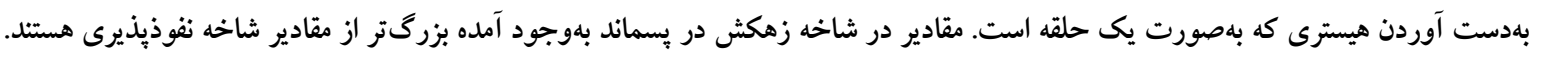

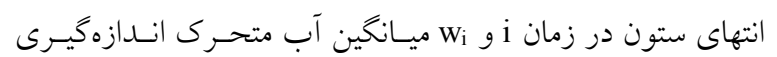
شده در زمان i است.

نتايج

مدلسازى آب ترجيحى با استفاده از روش موج سينماتيكى

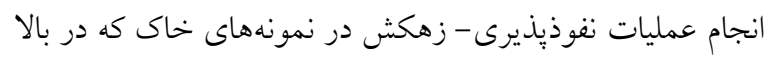

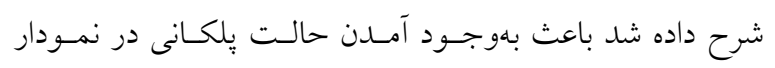

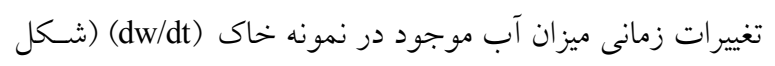

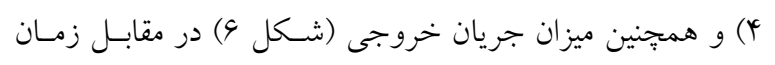

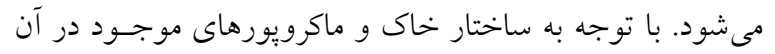

براى تخمين بارامترها با استفاده از مازول Solver در نرمافزار

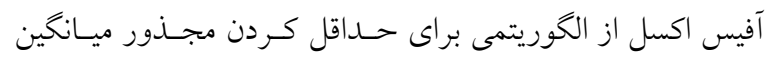

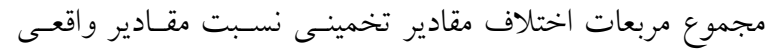
استفاده شد كه به نوعى نشاندهنده دقت و يـا خطساى (RMSE)

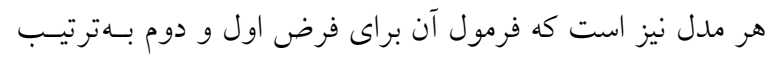
بلهورت روابط (YI) و (YT) مىشود: $\operatorname{RMSE}_{1}=\sqrt{\frac{1}{\mathrm{~N}} \sum_{\mathrm{i}}\left(\mathrm{u}_{\mathrm{i}}-\left(\mathrm{bw}_{\mathrm{i}}^{\mathrm{a}}\right)\right)^{r}}$

$\operatorname{RMSE}_{\mathrm{r}}=\sqrt{\frac{1}{\mathrm{~N}} \sum_{\mathrm{i}}\left(\mathrm{u}_{\mathrm{i}}-\left(\mathrm{bw}_{\mathrm{i}}^{\mathrm{a}}-\left.\mathrm{v}_{\mathrm{w}} \frac{\partial \mathrm{w}}{\partial \mathrm{t}}\right|_{\mathrm{i}}\right)\right)^{r}}$ كه در آنها N تعداد مقادير مشاهدهاى، Ui جريان مشاهده شـده در 

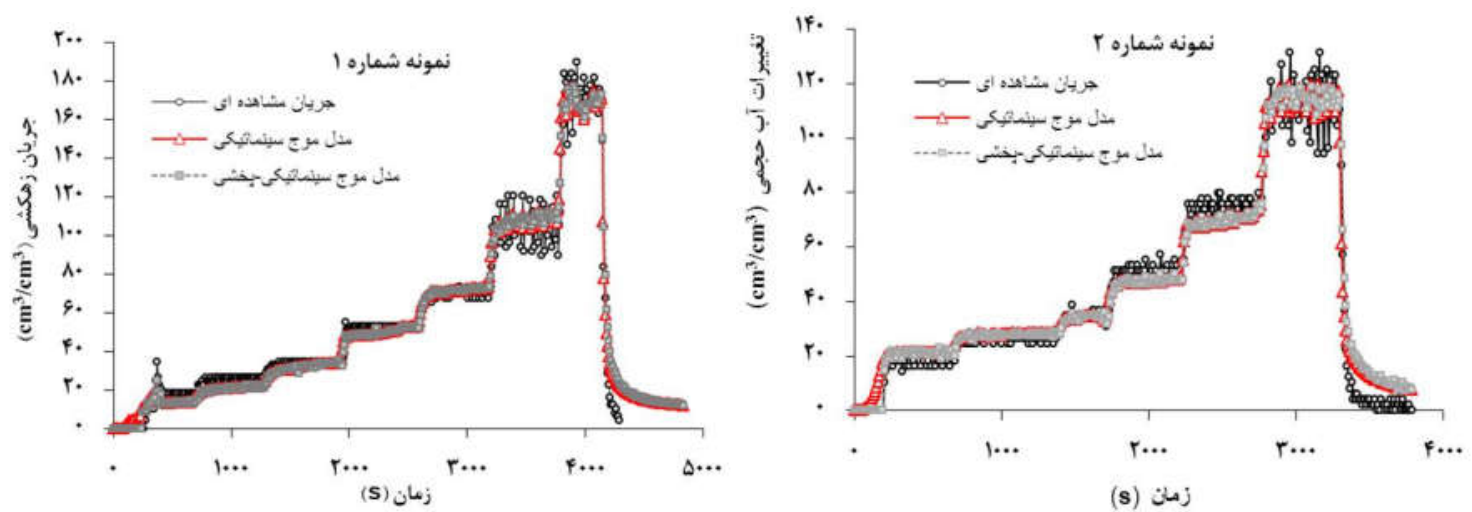

زمان (s)

شكل 9. منحنى بهدست آمده از دو مدل برازش داده شده موج سينماتيكى و موج سينماتيكى - بخشى براى نمونههاى شماره ا و Y و مقايسه آنها با دادهاى واقعى: شاخه زهكث دادههاى مشاهدهاى داراى شيب بيشترى است.

متفاوت است. همانطور كه ديده مىشود فرض دوم توانسته اسـت تـا حسـودى هيسـترى مـورد نظـر را ترسـيم كنـلد. در فـرض اول

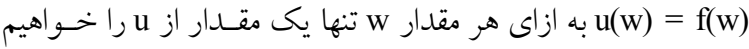
داشت، در نتيجه شيب شاخه نقوذيذيرى و زهكش تقريباً برابر بوده و به جاى يك حلقه، يك خط برازش داده شــه اسـت كـه خــود

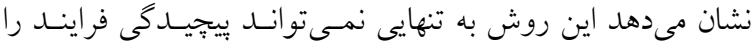
توضيح دهد. درحالى كه معادله (91) يعنى اضافه كردن جزء جريان

بخشى به موج سينماتيك تطابق خوبى با حلقه مورد نظر دارد. نكتهاى كه در اين جا قابل ذكر است، براى يك مقـدار ثابـت آب متحرى در داخل خاى مقـادير عـدد در شـاخه نفوذيـذيرى كو جكتر از شاخه زهكش است، جيزى كه در شكلهـاى (ه) و نيز (9) با توجه به شيب زياد شاخه زهكش ديده مسىشـود. ايسن مسئله متفاوت با تحقيقات ديخر محققان (V) است. معمولاً شاخه زهكش داراى شيب كمتر و براى يكى مقـدار معسين آب متحـرى داراى مقادير خروجى كمترى نيز است. علت اين امر مىتواند بـه نوع انجام اين آزمايش بركردد. در ديخـر مطالعـات هيـدروگراف خروجى يكى ركبار مصنوعى با شدت مشخص، در انتهاى سـتون اندازهيرى و ثبت شده است درحالى كه در ايسن مطالعسه در طى يك رويداد بارش، شدت بارش مصنوعى بهصـورت گَامبـهــام افزايش يافتهاست تا زمانى كه مقـدارى نخهاشــت سـطحى روى نمونه خاى ايجاد شود. احتمالاً همين امر سبب مىشود در انتهاى آزمايش مقدارى آب از كنارهها (محل اتصـال سـيلندر و خـاك)
اين عمليات را مىتوان تا زمان مشاهده آب در سطح خاك ادامـه داد. بهعلت خرابى يكى از ترازوها، جهار نمونه مورد ارزيابى قرار نخرفتند و نتايج مربوط به ها نمونه خاك در ايسن تحقيـق آورده شده است. در گام بعدى اقدام به مدلسازى اين جريان شد.

بهدست آوردن پِارامترهاى مدل و صحتسنجى مدل يارامترهاى مربوط به مدل در هر دو فرض با استفاده از دادههـاى : آزمايش نفوذيذيرى - زهكشى براى هر نمونه با استفاده از روابـط

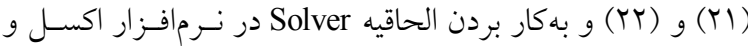
با حداقل كردن مقدار RMSE تعيين شدند.

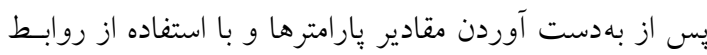

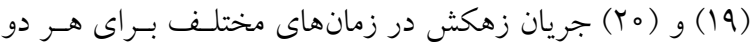
مدل بهدست آمد. سبر، جريان خروجى (u) بـهعنـوان تـابعى از ميزان آب متحرك داخل خاى (w) در هر دو مرحله نفوذيـذيرى و زهكث، بر روى يكى نمودار رسم شد (براى نمونسه شـكل ه). اينكار براى تمامى نمونههـا صـورت كرفـت. رابطـه u(w) يـك رابطه هيستريك است، بهطورىكه براى يك مقدار ثابت از جريان خروجى داراى دو عدد مختلـف يكى در شـاخه نفوذيـذيرى و ديخرى در شاخه زهكشى است. شكل (ه) براى نتايج مربوط به يك نمونـه آورده شـــه اسـت. حلقه بهوجود آمده نشان مى دهد كـه الخـوى نقوذيـذيرى (شـاخه صعودى هيدرو گراف جريان خروجى) نسبت بـهـ الخـوى زهكـش 
جدول ا. پارامترهاى بهدست آمده با استفاده از مدل اول و مدل دوم با فرض اصلاحى به همراه ميزان مجذور ميانكين مجموع مربعات خطاى حساب شده براى هر نمونه و مدل

\begin{tabular}{|c|c|c|c|c|c|c|c|}
\hline \multicolumn{2}{|c|}{ RMSE } & \multicolumn{3}{|c|}{ 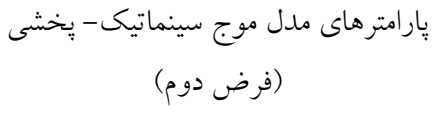 } & \multicolumn{2}{|c|}{$\begin{array}{c}\text { يارامترهاى مدل موج سينماتيكى } \\
\text { (فرض اول) }\end{array}$} & \multirow{2}{*}{ شمونه } \\
\hline فرض دوم & فرض اول & $\mathrm{V}(\mathrm{mm})$ & $\operatorname{logb}(\mathrm{mm} / \mathrm{h})$ & $\mathrm{a}(-)$ & $\log \mathrm{b}(\mathrm{mm} / \mathrm{h})$ & $\mathrm{a}(-)$ & \\
\hline G/AV & V/VV & TrND & $4 / \wedge D$ & T/T & 9/A & $r / \mu l$ & 1 \\
\hline$\Delta / \Delta V$ & $9 / 01$ & YN/GV & $9 / 99$ & $r / \circ \Lambda$ & $9 / 9 T$ & $r / 09$ & r \\
\hline $9 / \pi \wedge$ & $N / \Delta Y$ & $\varphi Q / 4 q$ & $V / r q$ & $r / T Y$ & V/Tr & $r / r l$ & r \\
\hline $1 \pi / 9 \Lambda$ & Ir/VT & $1 r / 4 q$ & $9 / 01$ & $r / 99$ & G/OT & r/Vo & r \\
\hline $11 / \pi 1$ & $11 / 40$ & $F q / 4 r$ & $19 / \mathrm{N}$ & Q/VQ & $19 / N^{2}$ & $Q / V Q$ & 0 \\
\hline $0 / \wedge q$ & $9 / \pi \mu$ & $r Y / \circ V$ & $0 / 90$ & $r / r q$ & $9 / 90$ & $r / r q$ & 9 \\
\hline$Y / V 。$ & $0 / 9 T$ & $10 / 4 \circ$ & $9 / N$ & $r / \mu_{0}$ & G/VA & $r / r \Lambda$ & V \\
\hline $\mid r / r_{0}$ & $1 r / \circ V$ & rG/V。 & $\Delta / \Lambda \Lambda$ & T/Vq & $\Delta / \Lambda Y$ & $r / \Lambda I$ & $\wedge$ \\
\hline$\Delta / \wedge 。$ & G/VG & rV/rA & $V / \wedge q$ & r/Ar & VIAT & r/vq & 9 \\
\hline T/VY & $Q / \circ P^{4}$ & GTM & $0 / 9 Y^{r}$ & $T / M V$ & V/AT & $r / v q$ & 10 \\
\hline
\end{tabular}

انجام است. آلير و همكاران (r) مرورى بر اين روشها دارند كـهـ براى مطالعه بيشتر قابل استفاده است. در اين مطالعه با يكى عمل تهل ابتكارى ميزان ماكرويورهـاى خـاك تعيسين شــه اسـت، كرجهـه

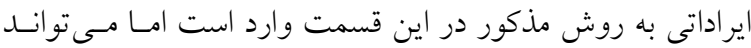
تقريبى از ميزان ماكرويورها بدهد. تعيين ماكرويورها برحسب درصد براى اين كار نياز به بارامترهاى زير است كه روش بهدست آوردن

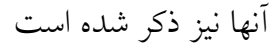

- - رطوبت اوليه (init): در حالتى كه ماكرويورهاى خاك خـالى از آب هستند، وزن كل نمونه-وزن نمونه خشـك شــده (در

آون در درجه حرارت همه إدرجه سانتى كراد)

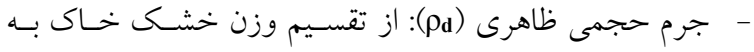
حجم سيلندر

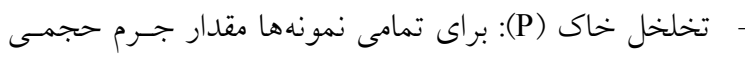

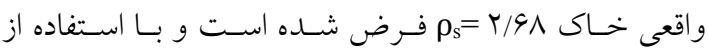
فرمول P كه خود شامل ماكرو و ميكرويورهاسـت
بهصورت جريان سريع باعث افزايش جريان خروجسى شـود. بـهـ

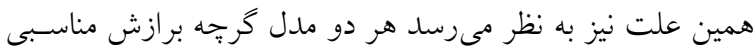
را دادهاند اما نتوانستهاند بهخوبى شاخه زهكش را برازش دهند. با مقايسه مقـادير RMSE در جــدول ا بــراى هـر دو مــدل، فرض دوم (در نظر كرفتن اثر بخش) در تمامى ه ا نمونسه خـاك داراى خطاى كمترى نسبت به فرض اول است كه نشان مىدهـــ افزودن اثر يخش باعث افزايش دقت تخمين هيدروكراف جريـان زهكش خروجى شده است. نقش ماكرويورها در جريان ترجيحى همانطور كه در بالا ذكر شد، ماكرويورها مسئول ايجـاد جريـان ترجيحى هستند؛ بنابراين فرض كلى اين است كـه هرجـه مقــدار ماكرويورها در خاك بيشتر باشد، جريان ترجيحى بيشترى وجـود

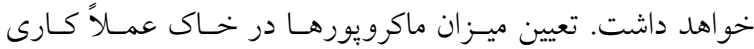
بسيار مشكل است كرته روشهـيى در حسال حاضـر همجهـون استفاده از رديابهاى رنكى و تكنيكهاى اسكن مـثلاً بسهوسـيله

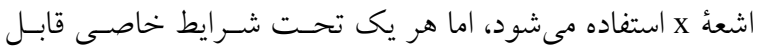


مدلسازى جريان ترجيحى با استفاده از مدل موج سينماتيك- يخشى (KDW)...

\begin{tabular}{|c|c|c|c|c|c|c|c|}
\hline \multicolumn{8}{|c|}{ جدول Y. مقدار ماكرويور فعال در داخل هر نمونه و پارامترهاى مورد نياز براى محاسبه آن } \\
\hline $\begin{array}{c}\text { ماكرويور فعال } \\
\text { (.) }\end{array}$ & $\begin{array}{c}\mathrm{q}_{\max } \\
(\mathrm{mm} / \mathrm{h})\end{array}$ & $\begin{array}{c}\Delta \theta_{\max } \\
(\%)\end{array}$ & $\begin{array}{c}\text { ميزان ماكرويور } \\
\text { (\%) }\end{array}$ & تخلخل (P) & $\rho_{\mathrm{d}}$ & $\begin{array}{l}\theta_{\text {init }} \\
(\%)\end{array}$ & شماره نمونه \\
\hline$\varphi / \circ \Delta$ & $\mid V T / 9$ & $\varphi / \circ \Delta$ & $9 / 49$ & $\Psi \wedge / 0$ & $1 / N$ & $\mu q / T \psi$ & 1 \\
\hline$r / l \varphi$ & $190 / \circ$ & $r / l t$ & $4 / 10$ & $01 / 1$ & $1 / 79$ & \&V/V。 & r \\
\hline$r / I V$ & $\mid Y N / 9$ & $\mathrm{r} / \mathrm{IV}$ & $9 / 0 \circ$ & $01 / \circ \circ$ & $1 / \mu_{0}$ & $Y \psi / D \circ$ & $r$ \\
\hline$r / 09$ & $111 / 1$ & T/D9 & $Y / T Q$ & $\varphi Q / D$ & $1 / 41$ & $F I / T Q$ & $\varphi$ \\
\hline$r / 00$ & $90 / \pi$ & Y/l。 & $\varphi / \varphi_{0}$ & $\varphi \varphi / 4$ & I/OT & KY/OO & 0 \\
\hline$Y / \Psi V$ & $94 / 00$ & $Y / \mathscr{E V}$ & $r / 4 \Delta$ & $\Psi 八 / \circ \circ$ & $1 / 49$ & $Y \Psi / D Q$ & 9 \\
\hline $1 / 09$ & $99 / 9$ & $1 / 09$ & $\varphi / \uparrow \wedge$ & $19 / 90$ & $1 / N y$ & $Y Q / \Delta T$ & V \\
\hline$T / I T$ & $q K / T_{0}$ & $r / I T$ & $\varphi / r_{0}$ & $4 q / Y_{0}$ & $1 / \pi 0$ & YY/A。 & $\wedge$ \\
\hline$r / 4 q$ & $\Delta 9 / Y_{0}$ & $r / 4 q$ & $Y / \Lambda \mu$ & $\Delta \circ / V \circ$ & $1 / \pi y$ & $Y Q / A V$ & 9 \\
\hline $1 / \mathrm{W}$ & $r 9 / 90$ & $1 / \mathrm{VV}$ & $\mathrm{r} / \Lambda \mathrm{r}$ & $\Delta T / \circ \circ$ & $1 / T \Lambda$ & YN/19 & 10 \\
\hline
\end{tabular}

نمونه خاك از رابطه زير بهدست آمد:

مقادير ذكـر شــده در جـدول ب آورده $\mathrm{MP}_{\mathrm{act}}=\theta_{\text {init }}+\Delta \theta_{\max }$ شده است.

بيش فرض اين بوده است كه ميزان دبى ترجيحى عبور كـرده از خاك در خلال آزمايش رابطـهاى مسـتقيم بــا مقــدار تخلخـل درشت يا همان ميزان ماكرويور خـاك دارد. بـه همسين دليـل در اولين گام نمودار شكل (V) براى بررسى آن رسم شد. همانطـور كه ديلده مىشود ميزان ضـريب تعيـين بـين مقـدار دبسى حسداكثر خروجى از نمونه خاك با ميزان كل ماكرويور (4س/

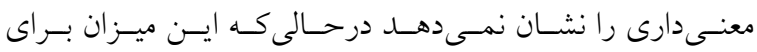
ماكرويورهاى فعال داراى رابطه معنىدارى با مقدار ضريب تبيسين است كه نشان مى R R = o/VDY

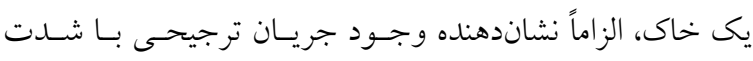
بيشتر نيست بلكه عامل مهم ماكرويورهـاى فنسال در يـك خـاك تعيين كننده ميزان حداكثر آب ترجيجـى عبـور كـرده هسـتند. از طرف ديخر ميزان حداكثر آب ترجيحى كه از سطح خـاك عبـور مى كند را مىتوان برابر با همان ميزان هدايت هيدروليكى قرار داد. از نكات ديخر اين تحقيق همانطور كه در جدول r ديده مىشود در اين آزمايش حداكثر ميزان ماكروبور فعال حدود هـ/4 درصــ
حــال اخـــر تمـامى تخلخهـل داراى آب باشـــ يعنسى تمـــى ماكرويورها و ميكرويورها يــر از آب هسـتند و خــاك اشـباع شده است. - مقدار كل ماكرويور يك نمونه خاى (M): حـال اخــر مقـدار تخلخل خاى (P) را از مقدار رطوبت اوليه (P) ) خـاك كــم كنيم، مقدار تقريبى تخلخل خاك بهدست خو اهد آمد.

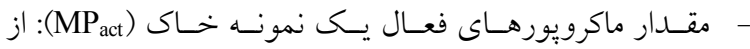
آنجايى كه تمـامى ماكرويورهـا در هـدايت جريـان ترجيحسى دخالت مستقيم ندارند مانند مواقعى كه انتهاى يك مـاكروبور بسته باشد، بنابراين بايستى مقدار تخلخل فعال در انتفـال آب ترجيجى را تعيين كرد. براى اين كار از مقـادير ثبـت شــده در

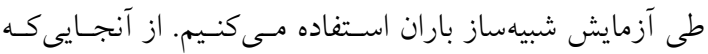
مقادير لحظهاى وزن آب در موجود در داخـل سـيلندر ثبـت

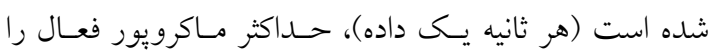
زمانى خواهيم داشت كـه نمونـه خـاك داراى حـــاكثر دبسى خروجى و يـا بـهـعبـارتى حــداكثر رطوبـت لحظـهاى باشـــ. بنابراين در هر مورد حداكثر دبى خروجى (q) و و تغييـرات حداكثر رطوبت ترجيحى لحظهاى ( بهطور جداكانه ثبت شد. بنابراين مقدار ماكرويور فعـال يـك 


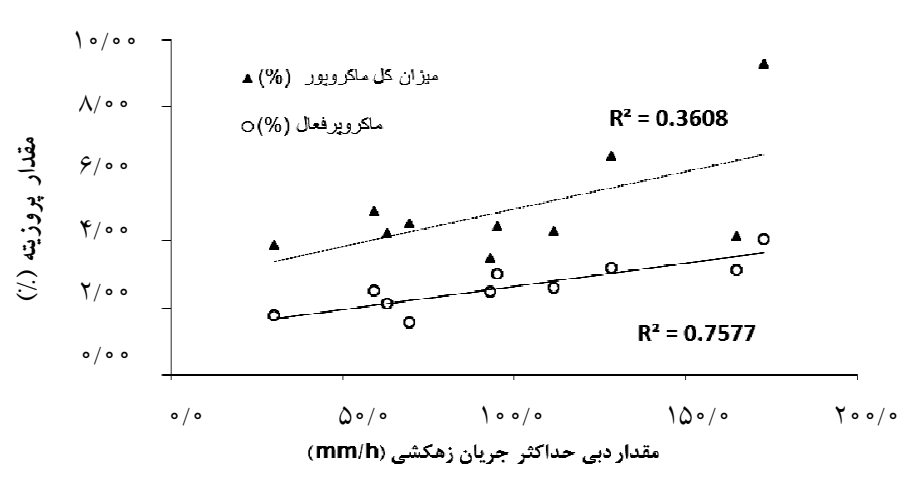

شكل V. برازش خطى ميزان مقدار دبى حداكثر خروجى از نمونه خاك با مقدار كل ماكرويور و ميزان ماكرويور فعال

مدل سينماتيكى در بيشبينى ميزان جريـان زهكش خروجسى را

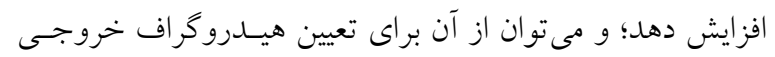

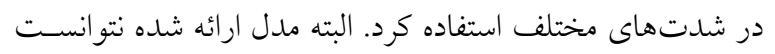

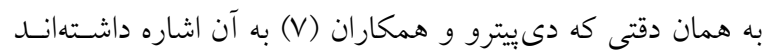

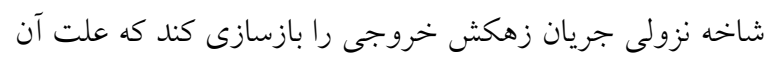

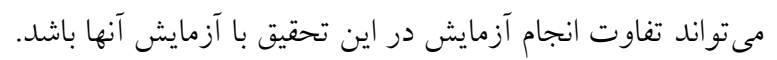
بيشنهاد مى شود كه در مطالعات بعدى دو مسئله يعنى استفاده از

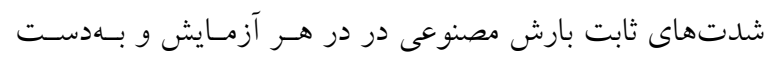

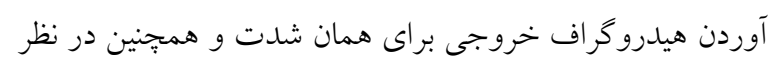

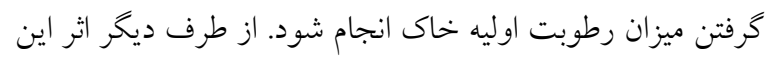

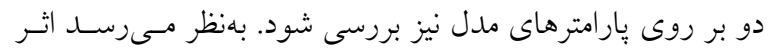

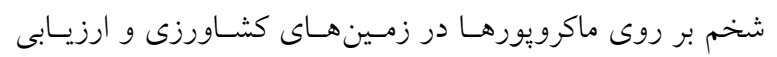

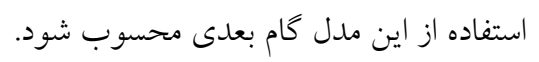

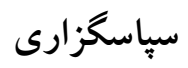
با تشكر از مركز انستيتو ملى تحقيقات كشاورزى اوينيون فرانسـه

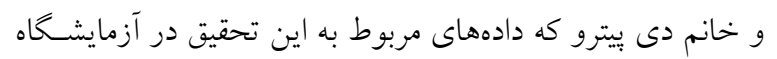
مكانيك خاى اين مؤسسه تهيه شده است.
از كل حجم خاك را تشكيل داده است كه نقش اصلى در انتقـال آب در داخل خاك را بر عهده دارد.

\section{نتيجه گيرى}

در ايسن مطالعـه مــدل ارائسه شــده توسـط جرمــان (9) و مــدل

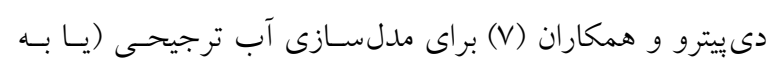

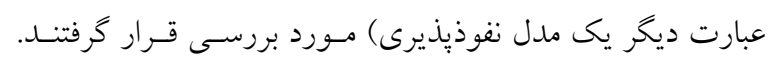

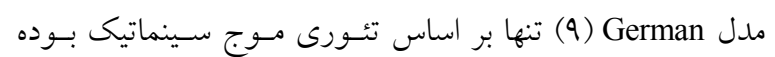

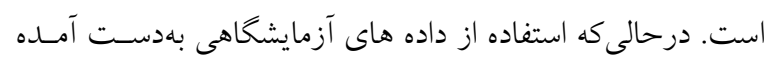
از ستون خاى و يا لايسيمترها نشان از اثـر بخ بخش (dispersion)

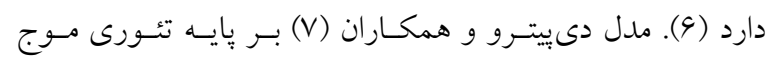

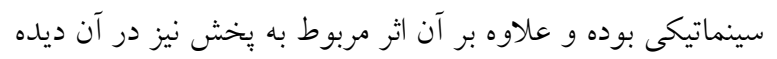

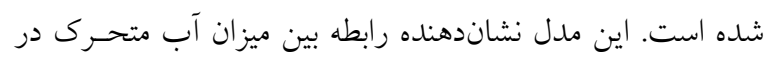

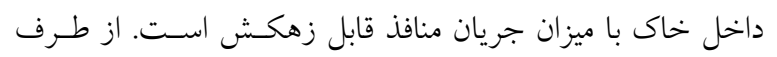

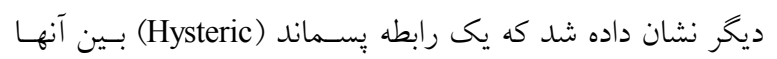

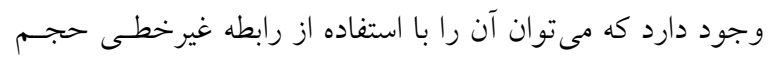

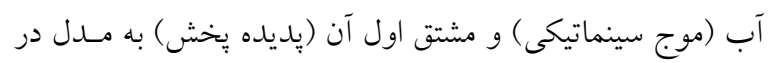

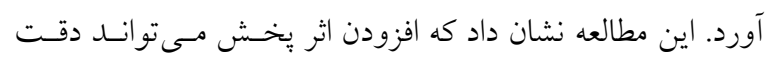

\section{منابع مورد استفاده}

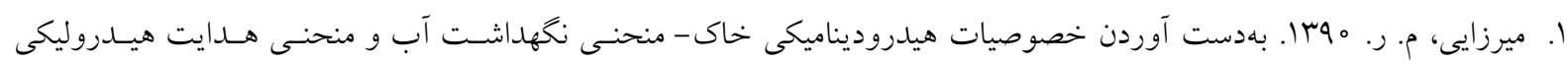

$$
\begin{aligned}
& \text { خاك- با روش Wind: مزايا و معايب. دوازدهمين كنخره علوم خاك ايران، دانشخاه تبريز. }
\end{aligned}
$$

2. Alaoui, A., P. Germann, N. Jarvis, and M. Acutis. 2003. Dual-porosity and kinematic wave approaches to assess the 
degree of preferential flow in an unsaturated soil. Hydrological Sciences Journal 48(3): 455-472.

3. Allaire, S. E., S. Roulier and A. J. Cessna. 2009. Quantifying preferential flow in soils: A review of different techniques. Journal of Hydrology 378(1-2): 179-204.

4. Allaire, S. E., S. Roulier and A. J. Cessna. 2009. Quantifying Preferential Flow in Soils: A Review of Different Techniques. Journal of Hydrology 378(1-2): 179-204.

5. Berod, D., V. Singh and A. Musy. 1999. A geomorphologic kinematic-wave (GKW) model for estimation of floods from small alpine watersheds. Hydrological Processes 13: 1391-1416.

6. Dekker, L. W., C. J. Ritsema, O. Wendroth, N. Jarvis, K. Oostindie, W. Pohl, M. Larsson and J. P. Gaudet. 1999 Moisture distributions and wetting rates of soils at experimental fields in the Netherlands, France, Sweden and Germany. Journal of Hydrology 215: 4-22.

7. Di Pietro, L. and P. Germann. 2001. Testing kinematic wave solutions for flow in microporous soils against a lattice-gas simulation. Soil Science Society of America Journal 56: 147-168.

8. Di Pietro, L., S. Ruy and Y. Capowiez. 2003. Predicting preferential water flow in soils by traveling-dispersive waves. Journal of Hydrology 278(1-4): 64-75.

9. Ethz, D. 2001. Mechanisms controlling macropore flow during infiltration dye tracer experiments and simulations. Swiss Federal Institute of Technology, Zürich.

10. Germann, P. 1985. Kinematic wave approximation to infiltration and drainage into and from soil macropores. Transactions ASAE 28: 745-749.

11. Germann, P. F., L. Di Pietro and V. P. Singh. 1997. Momentum of flow in soils assessed with TDR-moisture readings. Geoderma 80(1-2): 153-168.

12. Greco, R. 2002. Preferential flow in macroporous swelling soil with internal catchment: model development and applications. Journal of Hydrology 269(3-4): 150-168.

13. Jarvis, N. J. 1994. The MACRO Model Version 3.1-Technical Description and Sample Simulations. Reports and Dissertations no. 19. Department of Soil Science, Swedish University of Agricultural Sciences, Uppsala, Sweden.

14. Lighthill, M. and G. Whitham. 1995. On Kinematic Waves: 1. Flood Movement in Long Rivers. Series A. Royal Society, London.

15. Šimůnek, J., M. T. V. Genuchten and M. Sejna. 2006. The HYDRUS-1D Software Package for Simulating the Movement of Water, Heat, and Multiple Solutes in Variably-Saturated Media. Department of Environmental Sciences, University of California, California.

16. Simunek, J., O. Wendroth and M. T. Van Genuchten. 2003. Review and comparison of models for describing nonequilibrium and preferential flow and transport in the vadose zone. Journal of Hydrology 272(1-4): 14-35.

17. Singh, V. P. 2001. Kinematic wave modelling in water resources: a historical perspective. Hydrological Processes 15(4): 671-706.

18. Uchida, T., K. Kosugi and T. Mizuyama. 1999. Runoff characteristics of pipeflow and effects of pipeflow on rainfall-runoff phenomena in a mountainous watershed. Journal of Hydrology 222(1-4): 18-36.

19. Wang, Z., J. Feyen and C. J. Ritsema. 1998. Susceptibility and predictability of conditions for preferential flow. Water Resources Research 34: 2169-2182.

20. Zehe, E., H. Elsenbeer, F. Lindenmaier, K. Schulz and G. Bloschl. 2007. Patterns of predictability in hydrological threshold systems. Water Resources Research 43(7): 1-12. 


\title{
Preferential Flow Modeling Using Kinematic-Dispersive Wave Model and the Role of Macrospores
}

\author{
M. R. Mirzaei ${ }^{1 *}$ and S. Ruy²
}

(Received: November 23-2016; Accepted: January 8-2018)

\begin{abstract}
Preferential flow is of great importance in the environment and the human health. So, rapid water transportation and consequently, pollutants and pesticides leak out and get into the groundwater, making it very difficult to measure and quantify. To quantify and describe the preferential flow, two gravity-driven models were used: 1) kinematic wave model (KW) introduced by Germann in 1985), and 2) kinematic dispersive wave (KDW) model developed by applying a second-order correction to the Germann's model by Di Pietro et al. in 2003. So, the experimental data was obtained using the laboratory mini-rainfall-simulator over cylindrical soil samples at the laboratory. Their parameters were obtained using Solver add-ins in the Excel software. Then, the results were compared using the root-mean-square error (RMSE). The results showed that the KDW model could better predict the preferential flow (with lower RMSE). Also, the regression results showed 1) there was no significant relation between the preferential flow and the total porosity, and 2) there is a significant relation between the preferential flow and the macrospores.
\end{abstract}

Keywords: Preferential flow, Kinematic-dispersive wave model, Soil drainage hydrographs, Macrospores, Mini rainfall simulator

1. Department of Forestry, Faculty of Agriculture, Yasouj University, Yasouj, Iran.

2. National Institute for Agricultural Research, Avignon, France.

*: Corresponding Author, Email: mmirzaei@yu.ac.ir 